\title{
LATE EFFECTS OF INHALED PLUTONIUM IN DOGS
}

\author{
JAMES F. PARK \\ Biology Department, Battelle, Pacific Northwest Laboratories \\ Richland, Washington 99352
}
This report was prepared as an account of work sponsored by the United States Government. Neithe the United States nor the United States Atomic Energy Commission, nor any of their employees, nor any of their contractors, subcontractors, or their employees makes any warranty, express or implied, or assumes any egal liability or responsibility for the accuracy, com pleteness or usefulness of any information, apparatus, product or process disclosed, or represents that its use would not infringe privately owned rights.

1 Original and 2 copies submitted

No. of Manuscript Pages: 38

No. of Figures: 7

No. of Tables: 6 


\section{DISCLAIMER}

This report was prepared as an account of work sponsored by an agency of the United States Government. Neither the United States Government nor any agency Thereof, nor any of their employees, makes any warranty, express or implied, or assumes any legal liability or responsibility for the accuracy, completeness, or usefulness of any information, apparatus, product, or process disclosed, or represents that its use would not infringe privately owned rights. Reference herein to any specific commercial product, process, or service by trade name, trademark, manufacturer, or otherwise does not necessarily constitute or imply its endorsement, recommendation, or favoring by the United States Government or any agency thereof. The views and opinions of authors expressed herein do not necessarily state or reflect those of the United States Government or any agency thereof. 


\section{DISCLAIMER}

Portions of this document may be illegible in electronic image products. Images are produced from the best available original document. 
Running Head: Late Effects Inhaled Plutonium Dogs

Dr. James F. Park

Associate Manager

Biology Department

Battelle-Northwest

Richland, Washington 99352 
Park, J.F. Late Effects of Inhaled Plutonium in Dogs. Radiat. Res.

\section{ABSTRACT}

Pulmonary neoplasia was the primary cause of death in beagle dogs 5 to 10 years after inhalation of ${ }^{239} \mathrm{PuO}_{2}$ depositing 0.2 to $2.0 \mathrm{\mu C}$ in the lungs ( 3 to $22 \mathrm{nCi} / \mathrm{g}$.lung). Approximately $10 \%$ of the alveolar deposited plutonium was retained in the lungs 8 to 10 years postexposure with an estimated accumulated average radiation dose to the lungs of 2000 to 12,000 rads. Forty to fifty percent of the plutonium was translocated to the tracheobronchial and mediastinal. lymph nodes, 10 to $15 \%$ to the liver, $5 \%$ to the skeleton and $5 \%$ to the abdominal $1 y m p h$ nodes. The highest plutonium concentration occurred in the lymph nodes followed in descending order by lungs, liver and skeleton. Bone neoplasia was the primary cause of death in dogs 5 to 6 years after inhalation of ${ }^{238} \mathrm{PuO}_{2}$, depositing 2 to $5 \mu \mathrm{Ci}$ in the lungs (30 to $70 \mathrm{nCi} / \mathrm{g}$ lung). Thirty to fifty-five percent of the plutonium was in the skeleton 5 to 6 years postexposure with an estimated accumulated average radiation dose to the skeleton of 100 to 300 rads. Five to thirty percent of the $\mathrm{Pu}$ was in the lungs, 15 to $30 \%$ in the liver and 5 to $25 \%$ in the tracheobronchial and mediastinal iymph nodes. The highest plutoniun concentration occurred in the lymph nodes followed in descending order by Tiver, lung and skeleton.

After inhalation of ${ }^{238} \mathrm{PuO}_{2}$ or ${ }^{239} \mathrm{PuO}_{2}$ at these low levels, lymphopenia was the earliest observed effect, occurring 1 to 2 years after deposition of $\geq 80 \mathrm{nCi} \mathrm{Pu}$ in the lungs. 
This work was performed under United States Atomic Energy Conmission Contract AT(45-1)-1830. 


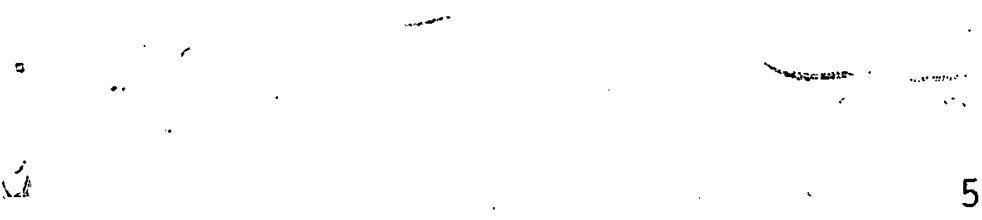

KEY WORDS: Inhalation

Plutonium .

Dogs

Neoplasia 


\section{INTRODUCTION}

The effects of inhaled ${ }^{239} \mathrm{PuO}_{2}$ and ${ }^{238} \mathrm{PuO}_{2}$ in beagle dogs were summarized in 1972 (1). More recently the effects of inhaled Pu in dogs compared with effects in other species $(2,3,4,5,6)$ and with effects of other radionuclides have been reviewed (7). This report is an overview summarizing effects of inhaled ${ }^{239} \mathrm{PuO}_{2}$ and ${ }^{238} \mathrm{PuO}_{2}$ in dogs with emphasis on dose-response relationships at low exposure Tevels.

EFFECTS OF INHALED ${ }^{239} \mathrm{PuO}_{2}$ IN BEAGLES

The following summary of the effects of inhaled ${ }^{239} \mathrm{PuO}_{2}$ was reported previously (1). Beagle dogs, 12-43 months old, were given single 10-30 min inhalation exposures to ${ }^{239} \mathrm{PuO}_{2}$ aerosols via a mask. The ${ }^{239} \mathrm{PuO}_{2}$ was obtained by clacining the plutonium oxalate in air at $300-350^{\circ} \mathrm{C}$. The count median diameter of the aerosol ranged from 0.1 to $0.5 \mathrm{\mu m}$.

of $65{ }^{239} \mathrm{PuO}_{2}$ dogs held for life-time observation, 62 died or were sacrificed when death was imminent between 55 and 4068 days after exposure. Figure 1 shows the relationship between the quantity of plutonium initially deposited in the lower respiratory tract or alveoli, in $\mathrm{nCi} / \mathrm{g}$ of bloodless lung, and the survival time of the 62 dogs. The curve, fitted to all the data, by least squares analysis, ran be extrapolated to $15 \mathrm{yr}$ postexposure 
(about 16 yr of age, the maximum expected life-span of these dogs) suggesting that deposition of more than $5 \mathrm{nC} \cdot \mathrm{j}$ per $\mathrm{g}$ of lung might be expected to cause premature death due to pulmonary neoplasia and pulmonary fibrosis-induced respiratory insufficiency. Thirtysix of the dags died between 55 and 1600 days postexposure due to plutonium-induced pulmonary edema, fibrosis and tronchiolar and alveolar epithelial hyperplasia and metaplasia, which resulted in severe respiratory insufficiency characterized by progressive hypercapnea and hypoxemia (8). Of the dogs that survived more than 1000 days after exposure, 24 had pulmonary neoplasia in addition to the fibrotic and metaplastic lesions. Twenty of the 21 dogs that survived more than 1600 days postexposure had pulmonary neoplasia. None of the control dogs, many of which are still alive, had pulmonary neoplasia. The incidence of primary pulmonary neoplasia in dogs has been reported to be $0.2-0.6 \%$ (9). Approximately $39 \%(24 / 62)$ of the dogs exposed to ${ }^{239} \mathrm{PuO}_{2}$ showed pulmonary neoplasia, however, $82 \%(24 / 29)$ of the exposed dogs that survived at least 1000 days had pulmonary neoplasia, and neariy $100 \%$ of those that survived more than 1600 days had pulmonary neoplasia.

Since mortality was due to two causes, pulmonary fibrosis and neoplasia, a curve was also fitted by least squares analysis to the data for just the dogs that showed puimonary neoplasia (Fig. 1). The slopes of the curves for all dogs and for just the tumor dogs were different; the intercepts at $15 \mathrm{yr}$ postexposure were about 5 and $3 \mathrm{nCi} / \mathrm{g}$, respectively. However, considering the spread of. 
the data points and the uncertainty in extrapolating the curves to $15 \mathrm{yr}$, a conservative estimate is that deposition of more than $1 \mathrm{nCi} / \mathrm{g}$ might be expected to cause premature death due to pulmonary neoplasia, or neoplasia and pulmonary fibrosis-induced respiratory insufficiency.

The estimated initial alveolar deposition in the dogs with plutonium-induced pulmonary tumors was $0.2-3.3 \mu \mathrm{Ci}$ or $3-45 \mathrm{nCi} / \mathrm{g}$ bloodless lung. This amount of plutonium is 100-1500 times the estimated maximum permissible lung burden (the quantity at equilibrium resulting in a mean dose of $0.3 \mathrm{rem} /$ week) for man, which is $0.016 \mu \mathrm{Ci}$ or about $0.03 \mathrm{nCi} / \mathrm{g}$ lung, assuming that the bloodless lung of man weighs $500 \mathrm{~g}$. The conservative estimate of $1 \mathrm{nCi} / \mathrm{g}$ initial deposition ( $270 \mathrm{nC} i$ in the total lung), causing premature death in the dog, is more than 30 times the concentration equivalent to the maximum permissible lung burden for man. This assumes that that induction of pulmonary tumors at low doses is related to plutonium concentration and not to total plutonium. If tumor induction is related to the total amount of plutonium, total number of particles, or total cells at risk, then the size of the human lung compared to the dog lung may not be important and $70 \mathrm{nC} i$ in the dog lung, causing premature death due to pulmonary cancer, may be only about 5 times the amount equivalent in hazard to the maximum permissible lung burden for man.

The morphology of these lung tumors was described previously $(10,11)$. Most were found to be bronchiolo-alveolar carcinomas of peripheral pulmonary origin. However, squamous cell carcinomas and epidermoid 
carcinomas were found in the lung, as well as bronchiolo-alveolar carcinomas. The majority of the tumors were peripheral in prinary site of origin, usually appeared to be multicentric, and were rather slow to invade the lymphatics or vascular system. Metastases were common to the tracheobronchial and mediastinal iymph nodes and lymphatics, and were less commonly seen in kidney, diaphragm, bone marrow, liver, adrenal and mesenteric lymph nodes.

The terminal bronchiolar and alveolar epithelium were the most frequent target cells for damage and neoplastic transformation, due to the residual localization of ${ }^{239} \mathrm{Pu}$ particles in the peripheral, especially subpleural, alveolar walls and associated scar tissue. The induced lesions consist primarily of pulmonary fibrosis, bronchiolo-alveolar epithelial hyperplasia and metaplasia, alveolar histiocyte proliferation; pleural fibrosis, and alveolar-cell tumor formation. Tumors were observed radiographically as early as 2 yrs prior to death $(8,12)$. In addition to the epithelial tumors in the lung, there have been a few pulmonary tumors of mesenchymal origin, including benigh-appearing lesions of endothelial oriyin which were classified as hemangiomas and lesions that appeared to be derived from the pleura or mediastinum which were histologically pleomorphic and probably represent mesothelioma.

Figure 2 shows the retention and translocation of alveolar-deposited plutonium in the 70 dogs. Approximately $10 \%$ of the alveolar-deposited plutonium was retained in the lungs at 11 yrs after exposure, having delivered an accumulated average radiation dose to the lungs of 
2000-12,000 rad. in the tumor bearing dogs. Forty to fifty percent of plutonium was translocated from the lung to the tracheobronchial and mediastinal lymph nodes (thoracic- 7 ymph nodes), with $10-15 \%$ going to the liver, $5 \%$ to the skeleton and $5 \%$ to the abdominal lymph nodes (hepatic and splenic Tymph nodes). About $85 \%$ of the plutonium initially deposited in the lower respiratory tract or alveoli was retained in the dogs 9-10 yrs after exposure. A dynamic simulation riodel for the biological disposition of inhaled ${ }^{239} \mathrm{PuO}_{2}$, developed with the aid of hybrid computer techniques and the data from these dogs, suggests that the clearance rate from the pulmonary compartment changes slowly and is best described mathematically by a power function (13). However, after the first 100 days, clearance of plutonium from the lung could be approximated by a half-time of 1000 days.

Table I shows the distribution of plutonium in the tissues of dogs 2500-3500 days after exposure. The highest concentration occurred in the tracheobronchial and medistinal $1 \mathrm{ymph}$ nodes, followed in descending order by abdominal lymph nodes, lungs, liver, other lymph nodes, spleen and skeleton. At 7-10 yrs after exposure, as much as $66 \%$ of the plutonium in the dogs was associated with the Tymphatic system. Pathology in the plutonium-containing lymph nodes consisted of severe necrosis of rymphoid tissue with histiocytic proliferation and scarring. Three of the dogs had thoracic lymph node lesions of endothelial. origin classified as hemangiosarcoma, 
lymphangiosarcoma and endothelioma. One dog had malignant lymphoma involving mainly the mesenteric and mandibular lymph nodes.

Respiratory insufficiency and Iymphopenia were the primary clinical signs associated with the fibrotic, metaplasic and neoplastic changes in the lungs and with the fibrosis of the lymph nodes. Figure 3 shows the mean leucocyte values of 14 dogs with body burdens of $0.2-1.0 \mu \mathrm{Ci}$. The mean 1ymphocyte count of the plutoniuriexposed dogs was less than the control dogs, 6 months after exposure, and continued to be $30-50 \%$ of the control-dog values for the subsequent period. The mean total leucocyte count of the plutoniuri-exposed dogs was frequently less than that of the control dogs, primarily due to the decrease in lymphocytes. Leucocyte counts were frequently elevated prior to death when the lungs were severely dariaged due to pulmonary neoplasia. There were no other significant changes observed in the hemogram of the plutonium-exposed dogs. The critical tissue related to lymphopenia is unknown. Yuile et al., (14) suggest that irradiation of circulating cells by plutonium in the lung and lymph nodes is responsible for 7 mmphopenia, rather than its resulting from a general depression of hematopoiesis and lymphopoiesis. It is possible that there is a relationship between plutonium-induced lymphopenia, lymph node pathology, and decreased immunological capability, and the pathogenesis of plutonium-induced pulmonary neoplasia.

The livers of some of the dogs that died showed passive congestion wilh central lobular degeneration. This was probably related to 
circulatory changes caused by severe lung pathology. No significant pathological changes were observed in the skeletons of these dogs that could be related to the plutonium in the skeleton. Two dogs that died of lung tunors had developed severe hypertrophic pulmonary osteoarthropathy secondary of the lung lesions. No primary neoplasia of the skeleton or liver, as described for intravenously administered ${ }^{239} \mathrm{Pu}$ citrate in beagle dogs (15), was observed following inhalation of ${ }^{239} \mathrm{PuO}_{2}$.

In the experiments described above, the incidence of pulmonary neoplasia in beagle dogs after inhalation of ${ }^{239} \mathrm{PuO}_{2}$ was nearly $100 \%$ at average plutonium doses 100-1500 times the maximum permissible level for man. Experiments were initiated in 1970 to study the dose-effect relationship of inhaled ${ }^{239} \mathrm{PuO}_{2}$ in beagle dogs depositingmuch lower levels - from 0.003 to $6.0 \mu \mathrm{Ci}$. Table II shows the experimental design. The lowest deposition level corresponds to an average lung dose of $0.3 \mathrm{rem} /$ week, the maximum pernissible exposure for man. The dogs will be held for life-time observation to determine the incidence of pulmonary neoplasia and evaluate other effects in beagle dogs at thesc low exposure levels. Eighteen-month old beagles were given 5 to $20 \mathrm{~min}$ exposures to aerosols of ${ }^{239} \mathrm{PuO}_{2}$ [mean activity median aerodynamic didneter (AMAD) 2.3 urn, mean geometric standard deviation (GSD) 1.9] prepared by calcining the oxalate at $750^{\circ} \mathrm{C}$ for 2 hours. The six dose-level groups ranged from 3 to $5800 \mathrm{nC}$ mean initial alveolar burden.

During the first two postexposure years, dogs in the highest level dose group were euthanized when death was imminent due to respiratory 
insufficiency. These dogs showed pulmonary fibrosis and fibrosis of the tracheobronchial and mediastinal lymph nodes. Clinical changes included increased respiration rate, anoxemia, hypoxemia and body weight loss associated with the pulmonary fibrosis-induced respiratory insufficiency and Tymphopenia. The effects and Pu distribution in these dogs were similar to that shown in Figure 1 for dogs 1 to 2 years after exposure. Twelve to thirty-four percent of the plutonium was in the thoracic lymph nodes with 64 to $88 \%$ in the lungs and less than $3 \%$ translocated to other tissues.

A dose-related lymphopenia was observed in the ${ }^{239} \mathrm{PuO}_{2}$ dogs (Fig. 4). The lymphopenia appeared to be related to initial alveolar burden, showing a greater depression in lymphocyte count at the high dose levels; and to time after exposure, the lower dose levels showing Tymphopenia later than the high-dose-level dogs. The groups with mean initial alveolar burdens of $80 \mathrm{nCi}$ and higher showed lymphopenia during the first 2 years after exposure, while the $22 \mathrm{nCi}$ and lower dose groups, were similar to controls. The higher dose-level groups also showed a leucopenia primarily due to the decrease in 1ymphocytes. No significant abnormalities were seen in other hematological and clinical chemistry measurements. The 1ymphopenia in the $80 \mathrm{nCi}$ group at 2 years postexposure is the lowest duse-level in which an effect of inhaled plutonium in dogs has been observed, to date. In previous experiments. (described above), dogs at the lowest level. studied died due to pulmonary neoplasia 8 to 11 years after initial alveolar deposition of 200 to $800 \mathrm{nCi}{ }^{239} \mathrm{PuO}_{2}$. These dogs also showed lymphopenia. The $80 \mathrm{nCi}$ dose level group is 5 times the 
$16 \mathrm{nCi}$ lung deposition which delivers an average radiation dose of $0.3 \mathrm{rem} /$ week to the human lung and is equivalent to a dose of about $12 \mathrm{rem} /$ week to the lung of a dog, 40 times the maximum permissible dose for people.

\section{EFFECT OF INHALED ${ }^{238} \mathrm{PuO}_{2}$ IN BEAGLES}

The acute toxicity and biological effects of inhaled ${ }^{238} \mathrm{PuO}_{2}$ (calcined at $700^{\circ} \mathrm{C}, \mathrm{CMD} 0.05 \mu \mathrm{m}$ ) in beagle dogs, to 185 days postexposure, was similar to that of ${ }^{239} \mathrm{PuO}_{2}$ at comparable radiation doses to the lungs. However, due to faster translocation from the lung of ${ }^{238} \mathrm{Pu}$, the initial deposition level required to produce the effect may differ (16). The dogs exposed to ${ }^{238} \mathrm{PuO}_{2}$ showed a higher rate of translocation to skeleton, up to $13 \%$ of the body burden after 6 months, compared with less than $1 \%$ for the ${ }^{239} \mathrm{Pu}$ dogs. Liver and other tissues also reflected this difference between the two plutonium isotopes (Table III).

Beagle dogs were exposed to aerosols of ${ }^{238} \mathrm{PuO}_{2}$ calcined at $350^{\circ} \mathrm{C}$ (CMD $0.1 \mu \mathrm{m}$ ) or ${ }^{238} \mathrm{PuO}_{2}$ crushed microspheres (CMD $0.1 \mu \mathrm{m}$ ) to determine the long-term disposition and biological effects. Eight of the 10 dogs exposed to $350^{\circ} \mathrm{C}$ calcined ${ }^{238} \mathrm{PuO}_{2}$ and eight of the 12 dogs exposed to ${ }^{238} \mathrm{PuO}_{2}$ crushed microspheres were euthanized when death was imminent during the 6-year postexposure period. Table IV shows the cause of death and the ${ }^{238} \mathrm{Pu}$ distribution in the tissues.

Two of the dogs were euthanized because of respiratory insufficiency. related to plutonium-induced pulmonary fibrosis. Eight dogs were 
euthanized because of plutonium-induced bone tumors

and six dogs died of causes not thought to be related to plutonium exposure. None of the 17. control dogs on the study have died. In addition to the lesions causing death, the dogs had fibrotic tracheobronchial lymph nodes, pulmonary fibrosis and nodular hyperplasia in the liver. The two high-level dogs that died due to respiratory insufficiency were the only dogs showing clinical pulmonary effects.

The dogs showed a persistent 7ymphopenia (Figures 5 and 6), which became apparent in both groups by 200 days after exposure. In the crushed inicrosphere-exposed dogs, the mean lymphocyte count of the six surviving, exposed dogs remained below that of controls at. 6 years postexposure. The total leucocyte count of the exposed dogs was frequently lower than that of controls, primarity due to the low lymphocyte counts and a small but consistent reduction in neutrophils (Figure 6). The mean 7 ymphocyte count of the $350^{\circ} \mathrm{C}$ calcined plutoniumexposed dogs was evident until 5 years postexposure when only four of the dogs with the lowest body burdens remained alive (Figure 5). The dogs in this group also showed a neutropenia which was apparent. I month to 2 years after exposure, when the higher dose level dogs were still alive. The dogs also showed a leucopenia due to the neutropenia and Tymphopenia. No significant changes were observed in other leucocytes, erythrocytes or hemoglobin. The lower initial mean lymphocyte values in the dogs exposed to crushed microspheres, compared to the $350^{\circ} \mathrm{C}$ calcined plutonium-exposed group, may be due to an age difference. The dogs werc exposed to $350^{\circ} \mathrm{C}$ calcined ${ }^{238} \mathrm{PuO}_{2}$ when 3 years old and to 
${ }^{238} \mathrm{PuO}_{2}$ crushed microspheres when 1 year old. 01der dogs generally show lower lymphocyte counts.

No differences were observed in serum blood urea nitrogen, creatinine, glucose, alkaline phosphatase, or glutamic oxalacetic transmainase. Mean serum glutamic pyruvic transaminase (SGPT) levels were not significantiy elevated compared to controls, however, the percentage of elevated SGPT values (> 55 units) in dogs receiving ${ }^{238} \mathrm{Pu}$ was higher than the controls. These changes may be related to plutonium-induced lesions in the liver and/or metastatic tumors.

Five years after exposure, the largest fraction of plutonium retained in the body was in the skeleton followed in descending order by liver, thoracic 7 ymph nodes and lung, Table IV. The highest plutonium concentration occurred in the lymph nodes followed in descending order by liver or lung and skeleton. The biological, effects observed during the 4 to 6 years following exposure to ${ }^{238} \mathrm{PuO}_{2}$ were primarily related to skeletal deposition; 8 dogs died due to bone tumors. Assuming a linear transiocation of plutonium from the lung to the skeleton over the postexposure period the estimated accumulated radiation dose to the skeleton of the bone tumor-bearing dogs was 100 to 300 rads. In studies with ${ }^{239} \mathrm{PuO}_{2}$, plutonium was retained primarily in the lungs and thoracic lymph nodes, and dogs died 3 to 11 years after inhalation exposure due to lung tumors; no bone tumors were observed. The importance of translocation from the lung, and of radiochemical and/or physical state on this translocation, is evident in these results. 
Microscopic examination of the tissues showed two dogs with metastasis of the bone tumor to the lungs. The lungs of all dogs showed focal epithelial metaplasia and fibrosis and one dog had microscopic evidence of pulmonary neoplasia. In addition one dog, not yet examined microscopically, showed radiographic evidence of pulmonary neoplasia several months prior to euthanization due to vertebral lesions suspected to be osteosarconia. The dog that died due to myelogeneous leukemia also had microscopically diagnosed bone tumors.

Experiments were initiated in 1972 to study the dose-effect relationships of inhaled ${ }^{238} \mathrm{PuO}_{2}$ beagles. Table $V$ shows the experimental design. Eighteen-month-old beagles were exposed to derosols of ${ }^{238} \mathrm{Pu}^{16} \mathrm{O}_{2}$ (mean AMAD 1.8 unl, mean GSD 1.9) prepared by calcining the oxalate at $700^{\circ} \mathrm{C}$ and subjecting the product to $\mathrm{H}_{2}^{16} \mathrm{O}$ steam in an exchange at $800^{\circ} \mathrm{C}$ for 96 hours. The mean initial alveolar burden in the six dose level groups range from 2 to $5200 \mathrm{nCi}$. The lowest deposition level corresponds to an average lung dose of $0.3 \mathrm{rem} / \mathrm{week}$, the maximum permissible exposure for man. This experiment and the previously described inhaled ${ }^{239} \mathrm{PuO}_{2}$ dose-effect relationship study will provide information on possible differences in the disposition and biological effects of inhaled ${ }^{239} \mathrm{PuO}_{2}$ and ${ }^{238} \mathrm{PuO}_{2}$, two similar alpha-emitting isotopes that differ by a factor of about 280 in specific activity.

During the first postexposure year none of the dogs have died, however, ten dogs were exposed to ${ }^{238} \mathrm{Pu}^{16} \mathrm{O}_{2}$ aerosols and sacrificed. for plutonium retention and translocation measurements $7,28,56$, and 
91 days after exposure. Table VI shows the tissue distribution of plutonium in these dogs compared to dogs sacrificed 7 to 141 days after inhalation of ${ }^{239} \mathrm{PuO}_{2}$. There appears to be more ${ }^{238} \mathrm{Pu}$ than ${ }^{239} \mathrm{Pu}$ translocated to the thoracic lymph' nodes, liver and skeleton during the 28 to 91 day postexposure period. Differences in the in vivo and in vitro behavior of ${ }^{238} \mathrm{PuO}_{2}$ and ${ }^{239} \mathrm{PuO}_{2}$ suggest that ${ }^{238} \mathrm{PuO}_{2}$ behaves as a more "soluble" compound than ${ }^{239} \mathrm{PuO}_{2}$ (17).

The ${ }^{238} \mathrm{Pu}^{16} \mathrm{O}_{2}$-exposed dogs also showed a dose-related 7 ymphopenia and leucopenia during the first year postexposure (Figure 5). The groups with mean initial alveolar deposition of $80 \mathrm{nCi}$ and higher showed lymphopenia while the lower dose groups were similar to controls. The highest dose-level group also showed a neutropenia.

\section{CONCLUSIONS}

With the dose-levels studied to date, plimonary neoplasia was the primary cause of death in beagles 5 to 10 yrs after inhalation of ${ }^{239} \mathrm{PuO}_{2}$. None of the dogs exposed to ${ }^{239} \mathrm{PuO}_{2}$ developed bone tuinors. Bone neoplasia was the primary cause of death 5 to 6 yrs after inhalation of ${ }^{238} \mathrm{PuO}_{2}$, however, two of the dogs had pulmonary tumors in addition to bone tumors.

The earliest indication of a biological effect after the inhalation of ${ }^{239} \mathrm{PuO}_{2}$ or ${ }^{238} \mathrm{PuO}_{2}$ was dose related Tymphopenia, occurring during the first two postexposure years at dose-levels lower than those which have thus far heen shown to cause neoplasia. The experiments now in 
progress will provide further information on the dose-response relationships of inhaled ${ }^{239} \mathrm{PuO}_{2}$ and ${ }^{238} \mathrm{PuO}_{2}$ at low exposure levels.

\section{ACKNOWLEDGEMENTS}

The author is indebted to many scientist and technicians involved in these studies, in particular to E. F. Blanton, D. L. Catt, D. K. Craig, J. R. Decker, G. L. Webb, and E. L. Wierman for exposure of dogs to plutonium aerosols, to J. S. Barnett, A. C. Case, J. P. Herring, and G. J. Powers for plutonium analyses, to H. A. Ragan for hematology, to P. L. Hackett for clinical chemistry, to G. E. Dagle and J. E. Lund for histopathology, to M. G. Brown and S. E. Rowe for animal care, to R. J. 01son and J. M. Thomas for statistical assistance, and to P. M. Bresina, E. H. Groff and J. A: Harrison for assistance in preparation of the manuscript. 


\section{REFERENCES}

1. J. F. Park, W. J. Bair, and R. H. Busch, Progress in beagle dog studies wi.th transuranium elements at Battelle-iNorthwest. Health Phys. $\underline{22}, 803-810$ (1972).

2. W. J. Bair and R. C. Thompson, Plutonium: biomedical research. Science 183, 715-722 (1974).

3. W. J. Bair, Toxicology of plutonium. In Advances in Radiation Biology Volume 4 (J. T. Lett; H. Adler, and M. Zelle; Eds.), pp. 255-315. Academic Press, Inc., New York, 1974.

4. R. C. Thompson, Effects of Plutonium in Animals. United States Atomic Energy Conmission Advisory Committee on Reactor Safeguards Special Report. (in press).

5. R. C. Thompson, Animal data on plutonium toxicity. Health P.hys. (in press).

6. W. J. Bair, Considerations in assessing the potential harm to populations exposed to low levels of plutonium in air. In Seminar on Padiological Safety Evaluation of Population Doses and Application of Radiological Safety Standards to Man and the Environment (L. A. Self, Ed.). Portoroz, Yugoslavia. (in press). 
7. W. J. Bair, J. E. Ballou, J. F. Park, and C. L. Sanders, Plutonium soft tissues with emphasis on the respiratory tract. In Uranium Plutonium Transplutonic Elements. (H. C. Hodge, J. N. Stannard, and J. B. Hursh, Eds.), pp. 503-568. Springer-Verlag, New York, 1973.

8. J. F. Park, W. J. Clarke, and W. J. Bair, Chronic effects of inhaled plutonium in dogs. Health Phys. 10, 1211-1217 (1964).

9. S. H. Nielsen, Pulmonary neoplasia in domestic animals. In Morphology of Experimental Respiratory Carcinogenesis (P. Nettesheim, M. G. Hanna, Jr., and J. W. Deatherage, Jr.; Eds.), p. 123-145. USAEC Document CONF 700501, NTIS, Springfield, VA, 1970 .

10. W. J. Clarke, J. F. Park, J. L. Palotay, and H. J. Bair, Plutonium inhalation studies VII. Bronchioloalveolar carcinoma of the canine lung following plutonium particle inhalation. Health Phys. 12, 609-613 (1966).

11. E. B. Howard, The morphology of experimental lung tumors in beagle dogs. 'In Morphology of Experimental Respiratory Carcinogenesis (P. Nettesheim, M. G. Hanna, Jr., and J. W. Deatherage, Jr., Eds.), p. 147-160. USAEC Document CONF 700501, NTIS, Springfield, VA, 1970 . 
12. J. F. Park, E. B. Howard; B. 0: Stuart, A. P. Wehner, and J. V. Dilley, Cocarcinogenesis studies in pulmonary carcinogenesis. In Morphology of Experimental Respiratory Carcinogenes is (P. Nettesheim, M. G. Hanna, Jr., and J. W. Deatherage, Jr., .Eds.), pp. 417-436. USAEC Docunent CONF 700501, NTIS, Springfield, VA, 1970.

13. B. O. Stuart, P. J. Dionne, and !. J. Bair, A dynamic simulation of the retention and translocation of inhaled plutonium oxide in beagle dogs. In Proc. 11th AEC Air Cleaning Conference (M. W. First and J. M. Morgan, Eds.), pp. 721-737. USAEC Document CONF 700816, NTIS, Springfield, VA, 1970.

14. C. L. Yuile, F. R. Gibb, and P. E. Mor'row, Dose-related local and systemic effects of inhaled plutonium-238 and plutonium-239 dioxide in dogs. Radiat. Res. 44, 821 (1970).

15. C. H. Mays and T. F. Douigherty, Progress in the beagle studies at the University of Utah. Health Phys. 22, 793-801 (1972).

16. J. F. Park, E. B. Howard, and W. J. Bair, Acutc toxicity of inhaled ${ }^{238} \mathrm{PuO}_{2}$ in beagles. In Pacific Northwest Laboratory Annual Report for 1968, pp. 3.6-3.13. BNULL-1050, Vol. 1, Pt. 1. Battelle-Nurtliwest, Richiand, WA, 1970. 
23

17. J. F. Park, D. L. Catt, D. K. Craig, R. J. 01son, and V. H. Smith, Solubility changes of ${ }^{238} \mathrm{Pu}$ oxide in water . suspension and effect on biological behavior after inhalation by beagle dogs. In Proc. of Third International Congress of the International Radiation Protection Association. Washington, D.C. (in press). 


\section{TABLE I}

Prutonium in tissues of dogs after inhalation of ${ }^{239} \mathrm{PuO}_{2}$

Pu Concentration ( $n C i$ per gram wet tissue) ${ }^{a}$

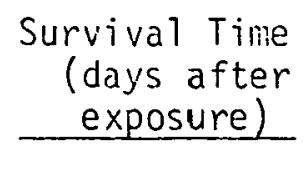

2565

2792

2809

$33: 3$

3447
Terminal body burden (uCi)

1.5

\begin{tabular}{|c|c|}
\hline Lungs $^{b}$ & Liver \\
\hline 1.1 & 1.1 \\
\hline (7) & (21) \\
\hline 1.2 & 0.5 \\
\hline
\end{tabular}

(14)

(23)

0.4

(21)

(21)

0.4

0.7

0.3

(13).

0.5

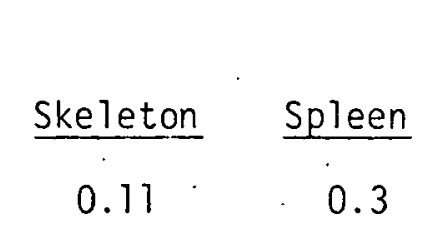

$\frac{\begin{array}{c}\text { Thoracic } \\ \text { lymph } \\ \text { nodes }\end{array}}{3700}$

\section{Abdominal}

lymph 110.11

(0.6)

(56)

0.11

0.4

1200

(10)

$(1.4)$

(41)

0.2

2600

160

0.03

$(0.7)$

(45)

(5)

0.1

420

210

(10)

$(0.6)$

0.2

0.03

(9)
$(0.7)$

(56)

180

(36)

The percertage of. the body burden of plutonium in each tissue is given in parenthesis.

The estimated normal weight of the lung was used to calculate concentration because lesions caused the lung to be 2-3.times the normal weight.

c Highest concentration in any tracheobronchial or mediastinal lymph node.

d Highest concentration in any hepatic or spleenic lymph node. 
TABLE II

Dose-Effect Studies with Inhaled ${ }^{239} \mathrm{PuO}_{2}$ in Beagles

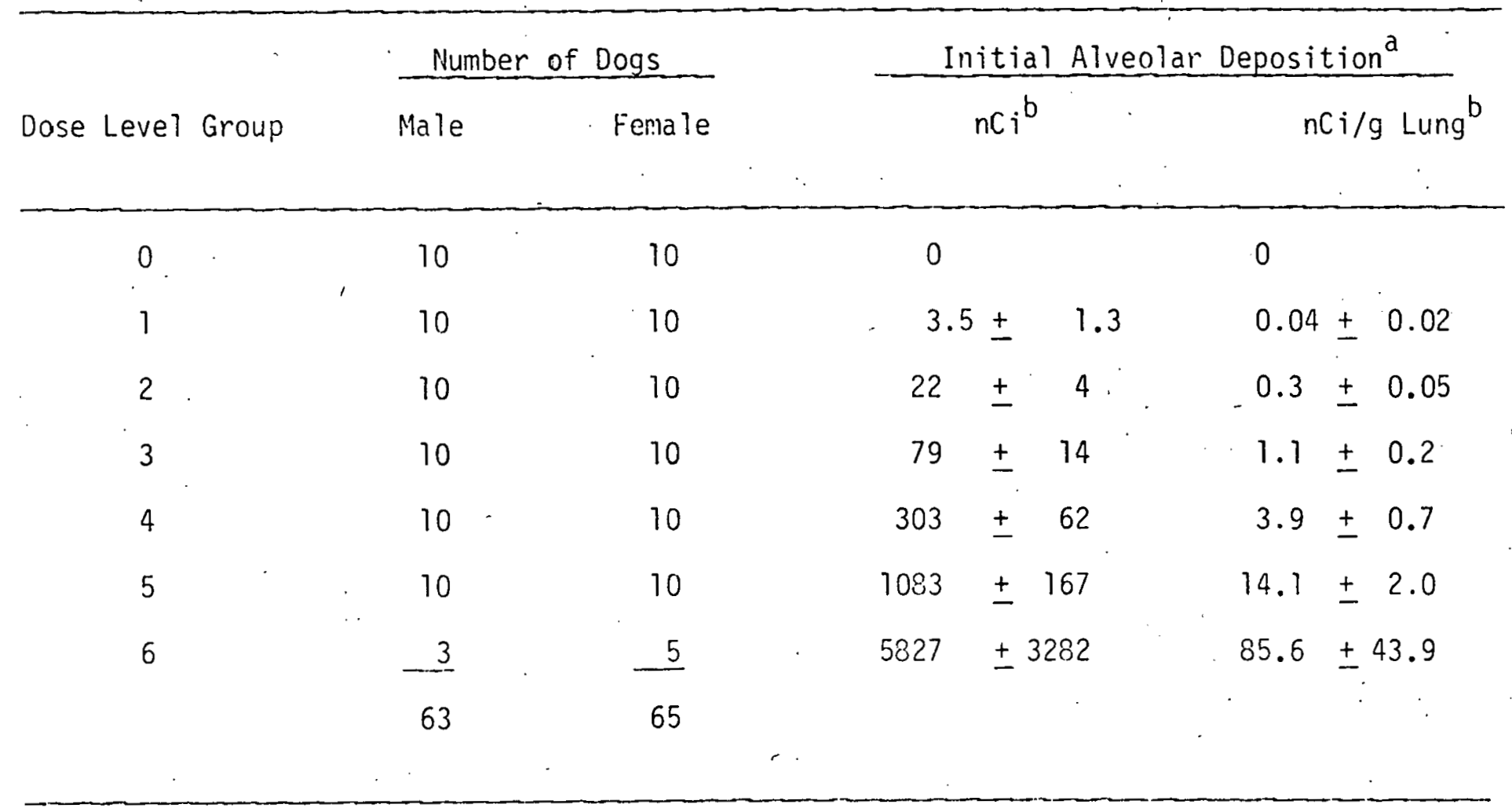

a Estimated from external thorax counts at 14- and 30-day postexposure and estiniated lung weights.

b Nean $\pm 95 \%$ confidence interval around the mean. 
TABLE III

Dog Mortality and Tissue Distribution After Inhalation of ${ }^{238} \mathrm{PuO}_{2}$

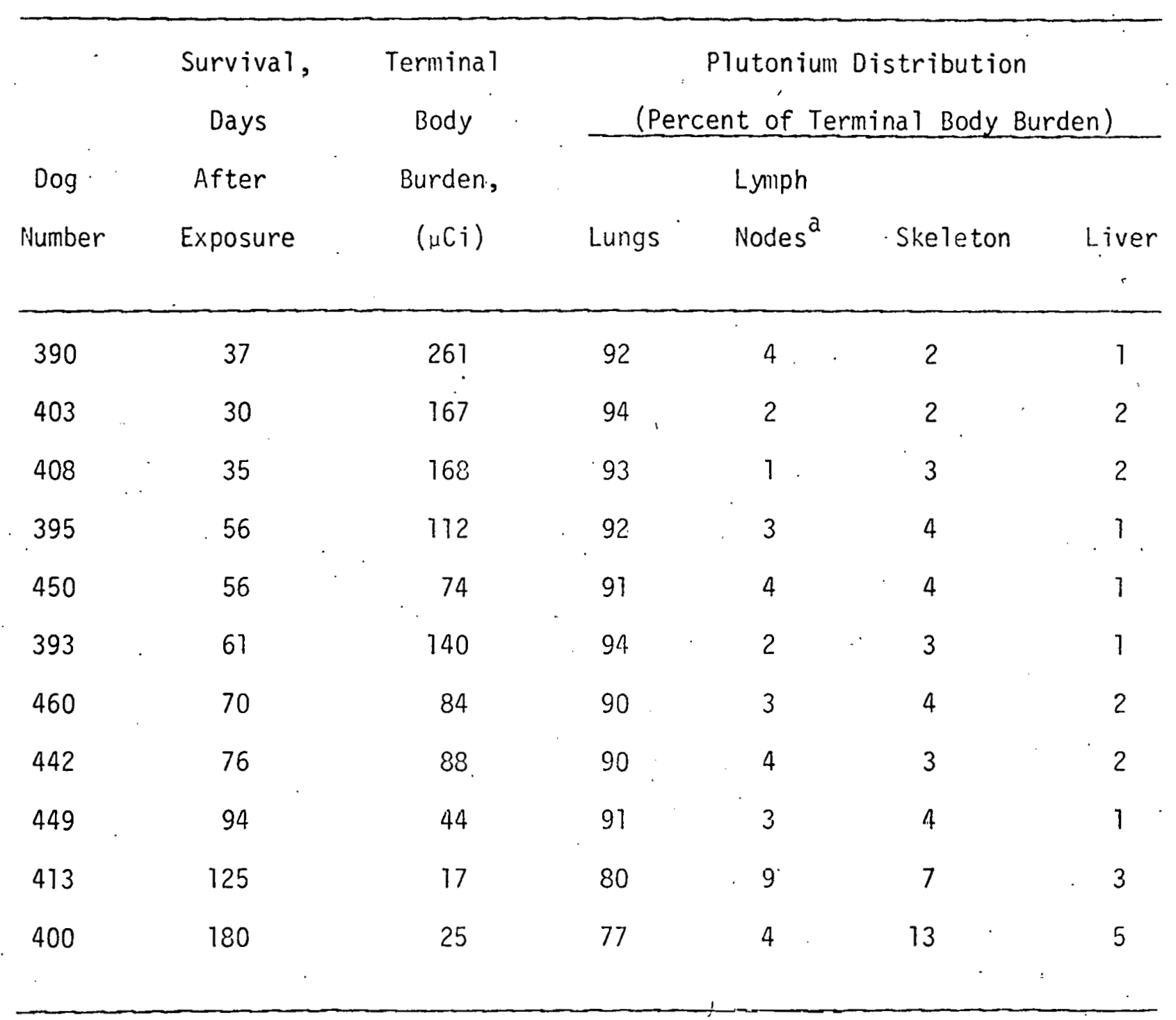

a Trar.heobronchial and mediastial lymph nodes. 
TABLE IV

Mertality and Tissue Distribution of Plutoniun in Dogs

\begin{tabular}{|c|c|c|c|c|c|c|c|}
\hline \multirow{3}{*}{$\begin{array}{l}\text { Dog } \\
\text { Number }\end{array}$} & \multirow{3}{*}{$\begin{array}{l}\text { Survival, } \\
\text { Months } \\
\text { After } \\
\text { Exposure }\end{array}$} & \multirow{3}{*}{$\begin{array}{c}\text { Terminal } \\
\text { Body } \\
\text { Burden } \\
\quad(! \mathrm{C} i)\end{array}$} & \multicolumn{4}{|c|}{$\begin{array}{l}\text { Plutonium Distribution } \\
\text { (Percent of Terininal Body Burden) }\end{array}$} & \\
\hline & & & \multirow[b]{2}{*}{ Lungs } & \multirow{2}{*}{$\begin{array}{l}\text { Lymph } \\
\text { Nodes }\end{array}$} & \multirow{2}{*}{ Liver } & \multirow{2}{*}{ Skeleton } & \\
\hline & & & & & & & \multirow[t]{2}{*}{ Cause of Death } \\
\hline \multicolumn{7}{|c|}{ (After Inhalation of ${ }^{238} \mathrm{PuO}_{2}$ Calcined at $350^{\circ} \mathrm{C}$ ) } & \\
\hline 492 & 23 & 3.0 & 4 & 4 & 23 & 64 & Bone Fracture \\
\hline 4104 & 36 & 8.1 & 32 & 10 & 23 & 32 & Respiratory Insufficiency \\
\hline 457 & 38 & 7.0 & . 15 & 11 & 13 & 57 & Respiratory Insufficiency \\
\hline 459 & 54 & 2.6 & .34 & 5 & 17 & 41 & Bone Tumor \\
\hline 445 & 58 & 2.5 & 6 & 10 & 23 & 55 & Bone Tumor \\
\hline 438 & 60 & 2.3 & 7 & 11 & 33 & 43 & Bone Tumor \\
\hline 453 & 62 & 2.2 & 17 & 9 & 22 & 47 & Bone Tumor \\
\hline 405 & 70 & $4.0^{\mathrm{a}}$ & & . & & & Bone Tumor ${ }^{c}$ (Lung Tumor) ${ }^{d}$ \\
\hline
\end{tabular}


TABLE IV (Continued)

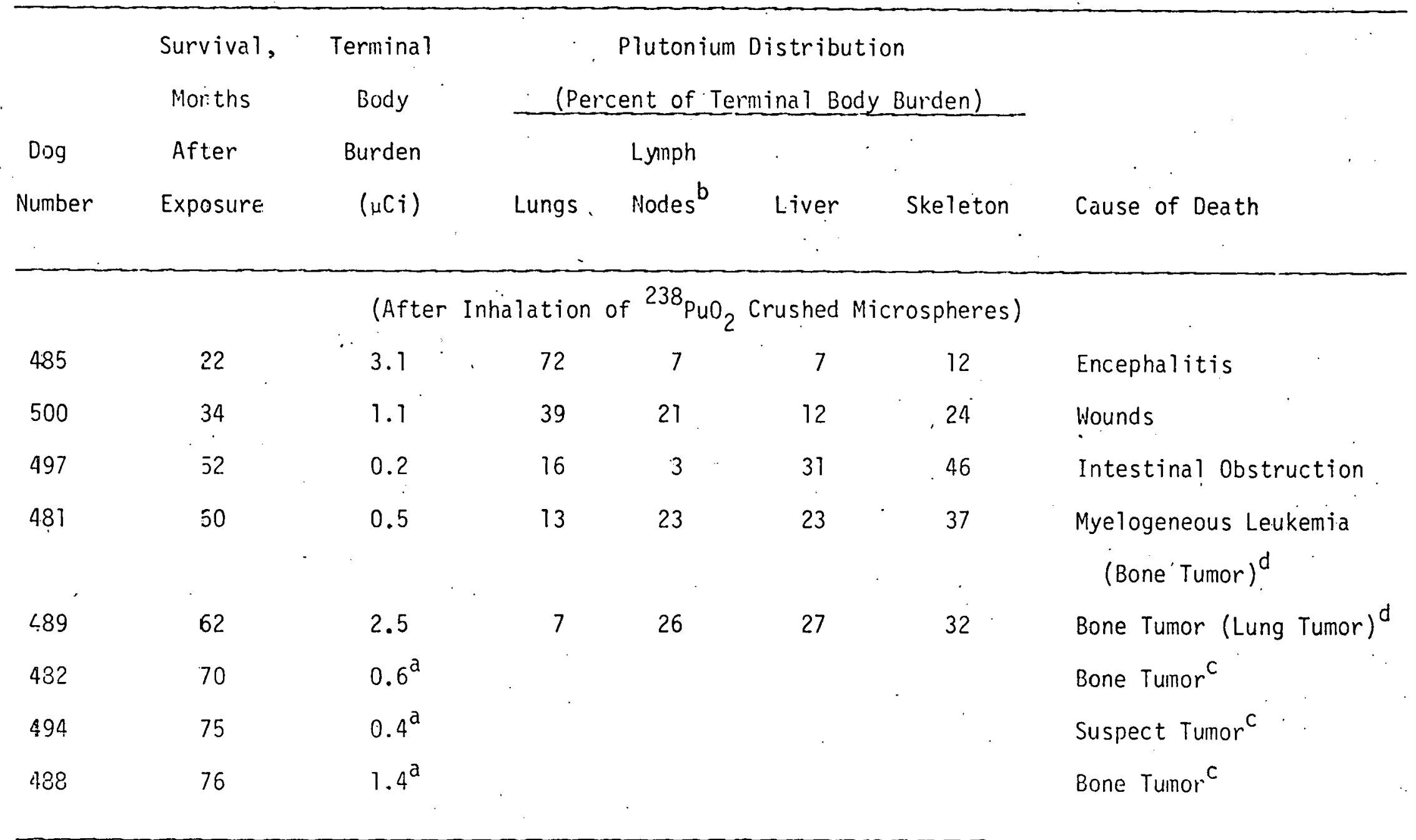

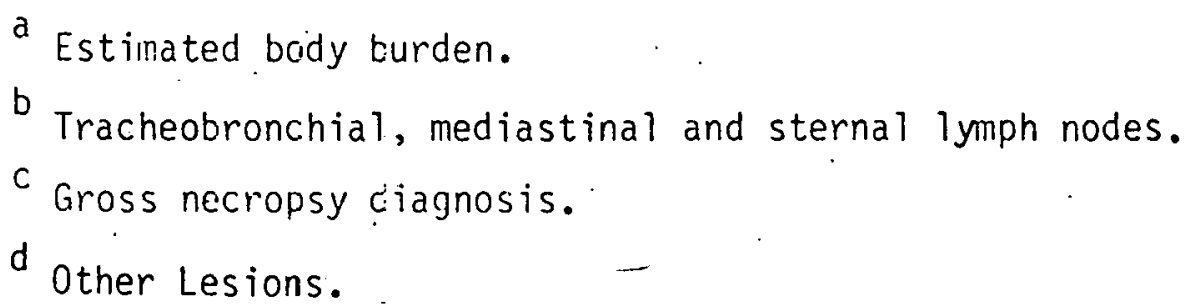


TABLE V

Dose-Effect studies with Inhaled ${ }^{238} \mathrm{Pu}^{16} \mathrm{O}_{2}$ in Dogs

\begin{tabular}{|c|c|c|c|c|c|}
\hline \multirow[b]{2}{*}{ Dose Level Group } & \multicolumn{2}{|c|}{ Number of Dogs } & \multicolumn{3}{|c|}{ Initial Alveolar Deposition } \\
\hline & Male & Female & & $n C i^{b}$ & $n C i / g$ lung ${ }^{b}$ \\
\hline 0 & 10 & .10 & 0 & & 0 \\
\hline 1 & 10 & 10 & 2. & 0.8 & $0.02 \pm 0.01$ \\
\hline 2 & 10 & 10 & 18 & \pm & $0.2 \pm 0.04$ \\
\hline 3 & 10 & 10 & 77 & \pm 11 & $1.1 \pm 0.4$ \\
\hline 4 & 10 & 10 & 354 & \pm 81 & $4.4 \pm 0.9$ \\
\hline 5 & 10 & 10 & 1308 & \pm 270 & $16.9 \pm 2.9$ \\
\hline \multirow[t]{2}{*}{6} & 7 & 6 & 5192 & \pm 1372 & $69.2+17.8$ \\
\hline & 67 & 66 & & & \\
\hline
\end{tabular}

a Estimated from external thorax counts at 14- and 30-day postexposure and estimated lung weights.

b Mean $\pm 95 \%$ confidence interval around the mean. 
TABLE VI

Tissue Distribution of Plutonium in Dogs After Inhalation of ${ }^{238} \mathrm{Pu}^{16} \mathrm{O}_{2}$ or ${ }^{239} \mathrm{PuO}_{2}$

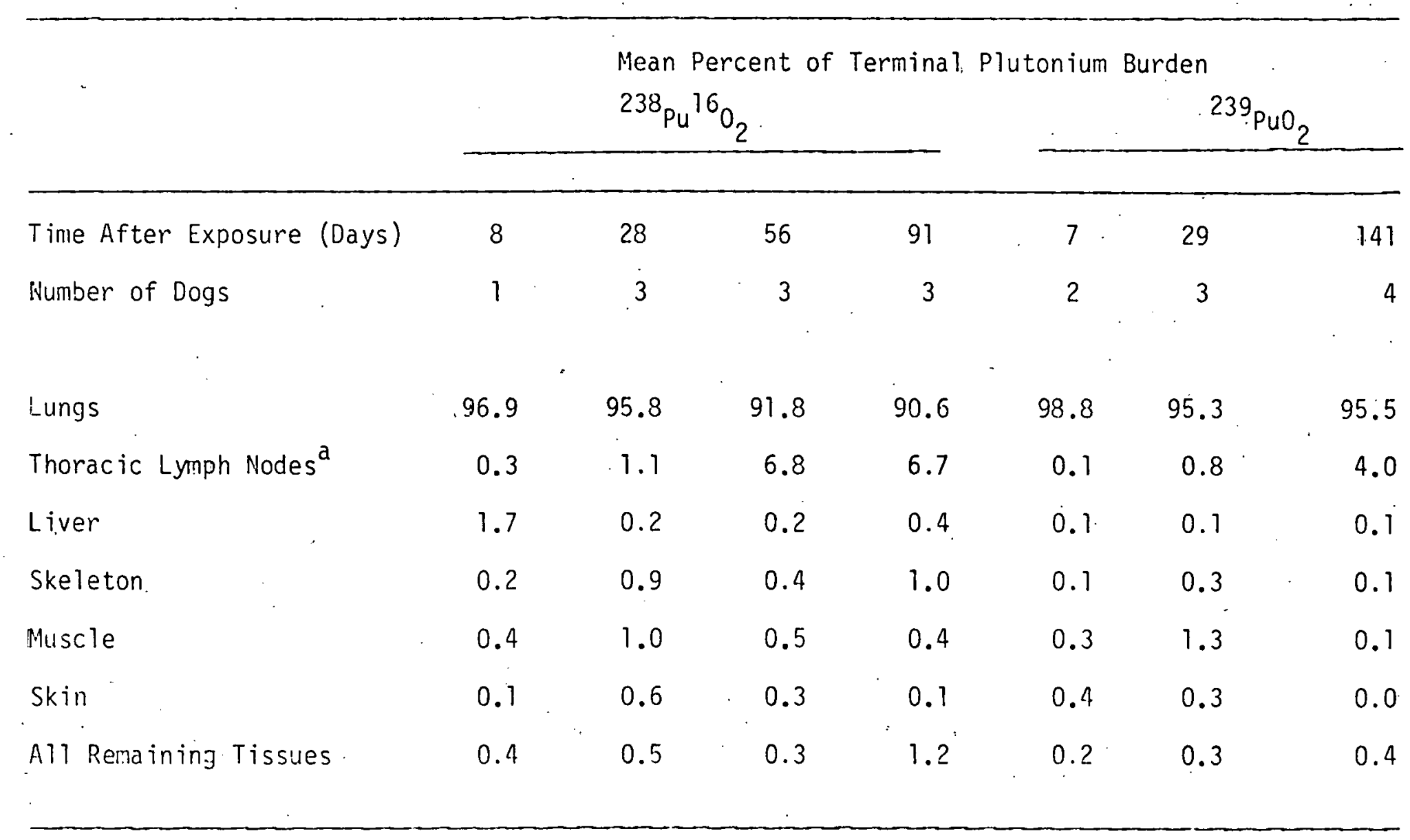

a Tracheobronchial, mediastinal and sternal lymph nodes. 


\section{FIGURE LEGENDS}

Figure 1. Relationship between the quantity of ${ }^{239} \mathrm{PuO}_{2}$ deposited and" survival tirie of dogs with pulmonary neoplasia and/or puimonary fibrosis (--) compared with dogs that showed puimonary neoplasia $(-)$.

Figure 2. Retention and translocation of alveolar deposited ${ }^{239} \mathrm{PuO}_{2}$ in dogs.

Figure 3. Leucocyte values of dogs showing lymphopenia after inhalation of ${ }^{239} \mathrm{PuO}_{2}$.

Figure 4. Leucocyte values of dogs after inhalation of $239 \mathrm{PuO}_{2}$ showing lymphopenia dose-response relationships. (Means \pm Confidence Interval).

Figure 5. Leucocyte values of dogs after inhalation of ${ }^{238} \mathrm{PuO}_{2}$ calcined at $350^{\circ}$ showing lymphopenia. (Means $\pm 95 \%$ Confidence Interva 1 ).

Figure 6. Leucocyte values of dogs after inhalation of ${ }^{238} \mathrm{PuO}_{2}$ crushed microspheres showing Tymphopenia. (Means $\pm 95 \%$ Confidence Interval).

Figure 7. Leucocyte values of dogs after inhalation of ${ }^{238} \mathrm{Pu}^{16} \mathrm{C}_{2}$ showing lymphopenia dose-response relationships. (Means $\pm 95 \%$ Confidence Interval). 


\section{FIGURE 1}

Relationship between the quantity of ${ }^{239} \mathrm{PuO}_{2}$ deposited. and survival time of dogs with pulmonary neoplasia and/or pulmonary fibrusis (--) compared with dogs that showed pulmonary neoplasia (-). 
RELATIONSHIP BETWEEN THE QUANTITY OF ${ }^{239} \mathrm{PUO}$
DEPOSITED AND SURVIVAL TIME OF DOGS

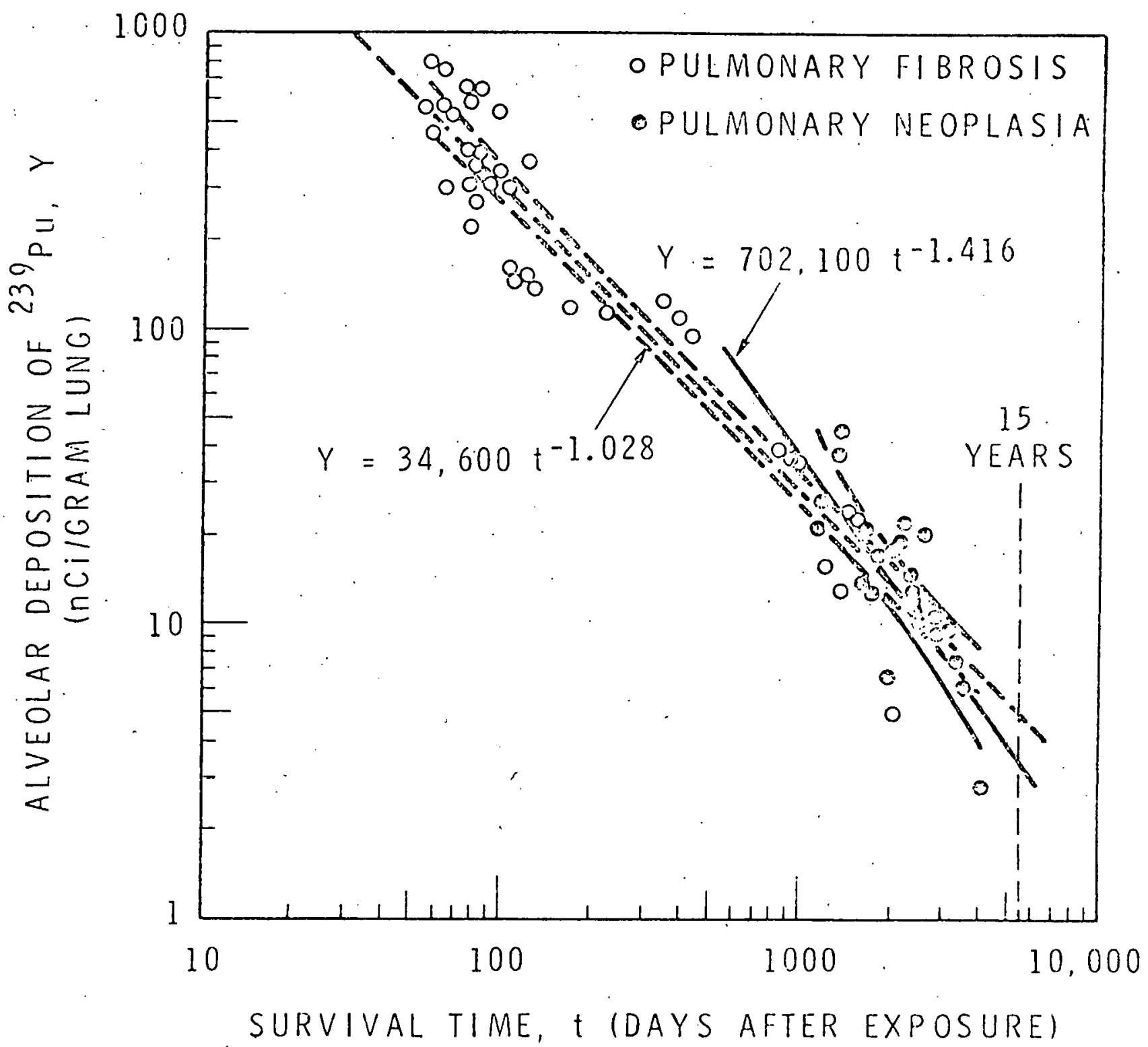




\section{FIGURE 2}

Retention and transiocation of alveolar deposited ${ }^{239} \mathrm{PuO}_{2}$ in dogs. 


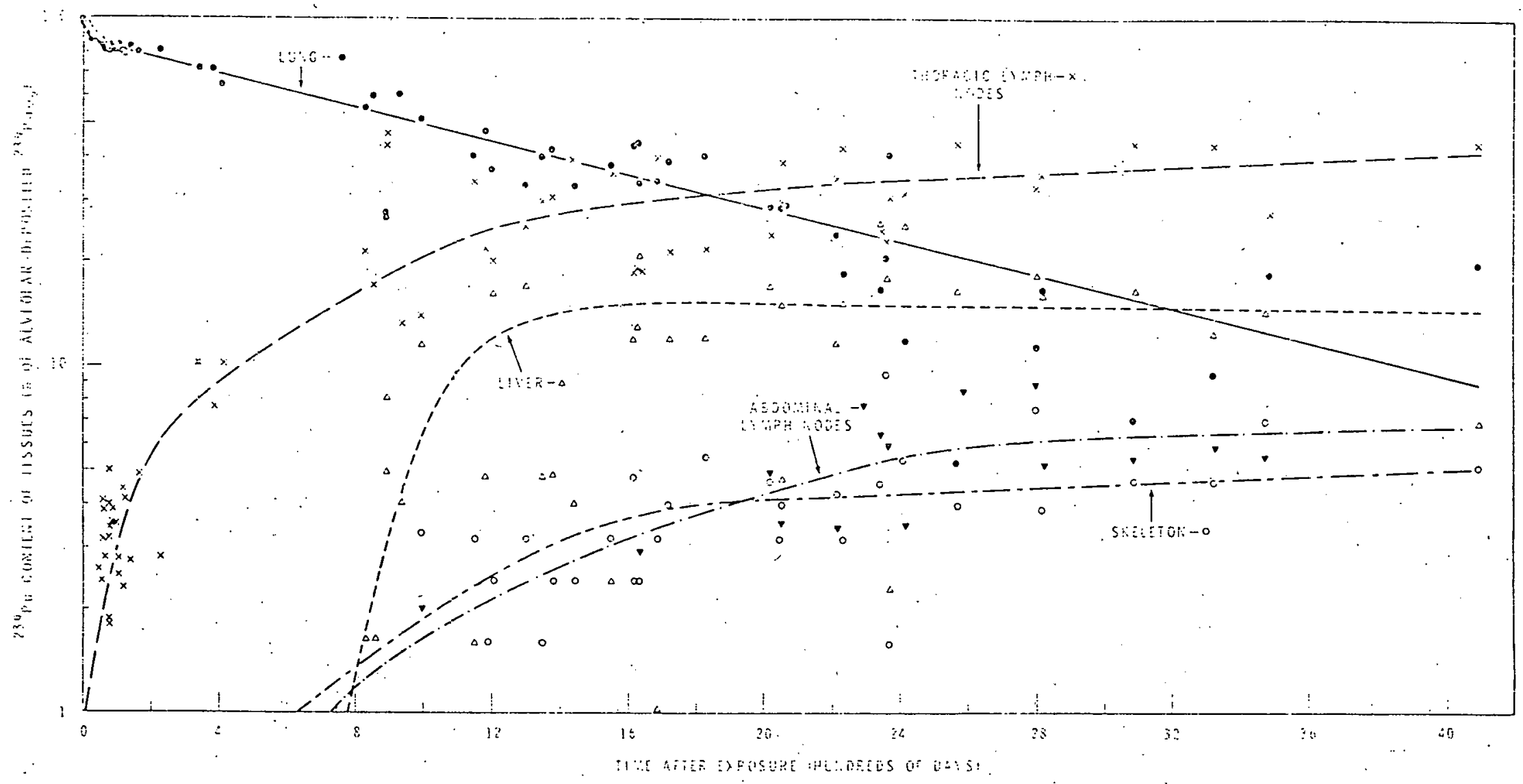




\section{FIGURE 3}

Leucocyte values of dogs showing lymphopenia after inhalation of $239 \mathrm{PuO}_{2}$. 
LEUCOCYIE VALUES OF BEAGLES AFTER LiHALAMION OF ${ }^{239} \mathrm{PUO}_{2}$

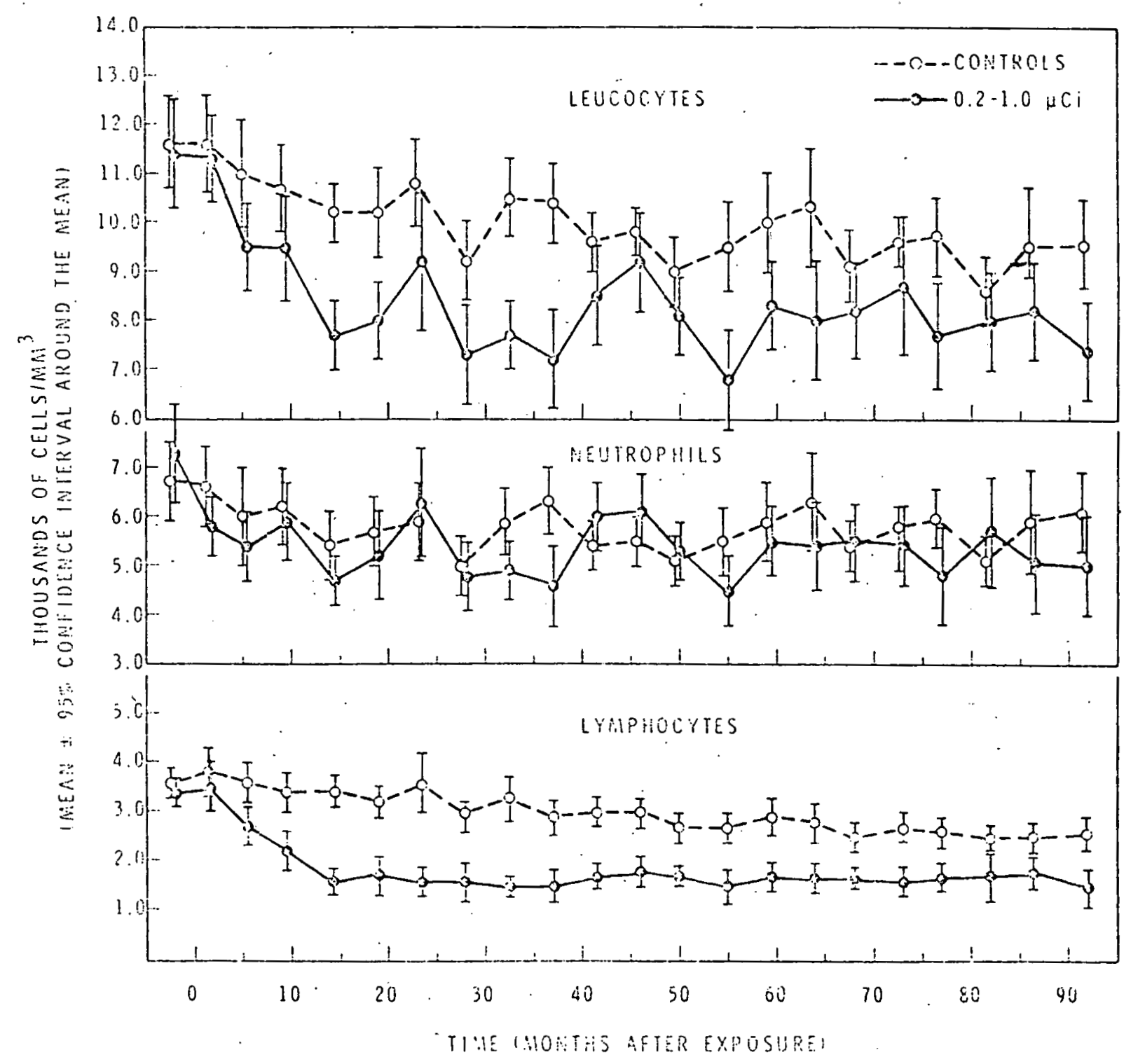




\section{FIGURE 4}

Leucocyte values of dogs after inhalation of ${ }^{239} \mathrm{PuO}_{2}$ sho:uing lymphopenia dose-response relationships.

(heans $\pm 95 \%$ Confidence Interval) 
LEUCOCYTE VALUES OF DOGS AFTER INHALATION OF ${ }^{239} \mathrm{PUO}_{2}$ (MEANS $\pm 9 \% \%$ CONFIDENCE INTERVAL).

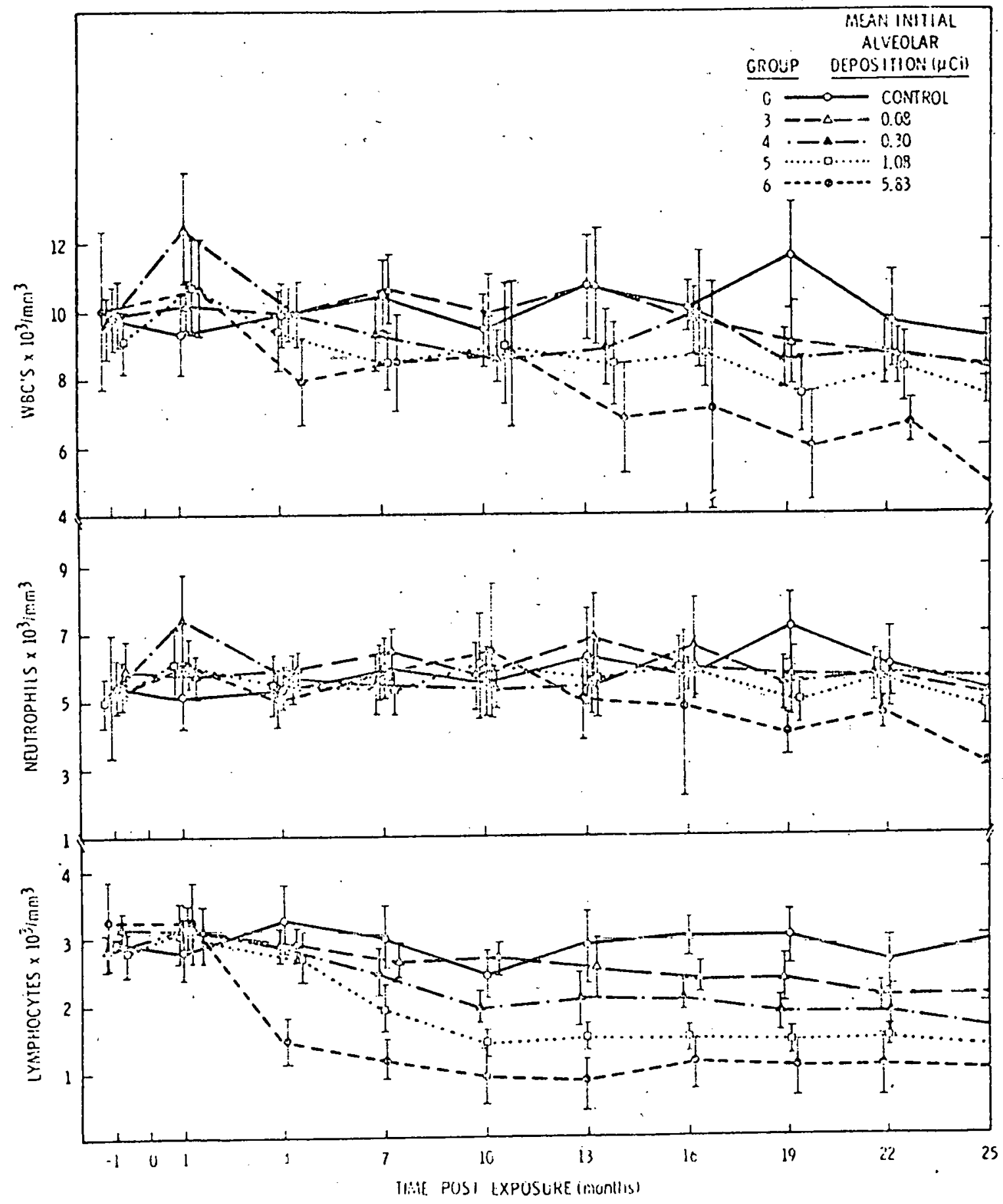


FIGURE 5

Leucocyte values of dogs after inhalation of ${ }^{233} \mathrm{PuO}_{2}$ calcined at $350^{\circ}$ showing lymphopenia.

(Means $\pm 95 \%$ Confidence Interval) 


\section{LEUCOCYTE VALUES OF DOGS AFTER INHALATION OF ${ }^{238} \mathrm{PuO}_{2}$ CALCINED AT $350^{\circ} \mathrm{C}$ (MEANS $\pm 95 \%$ CONFIDENCE INTERVAL)}
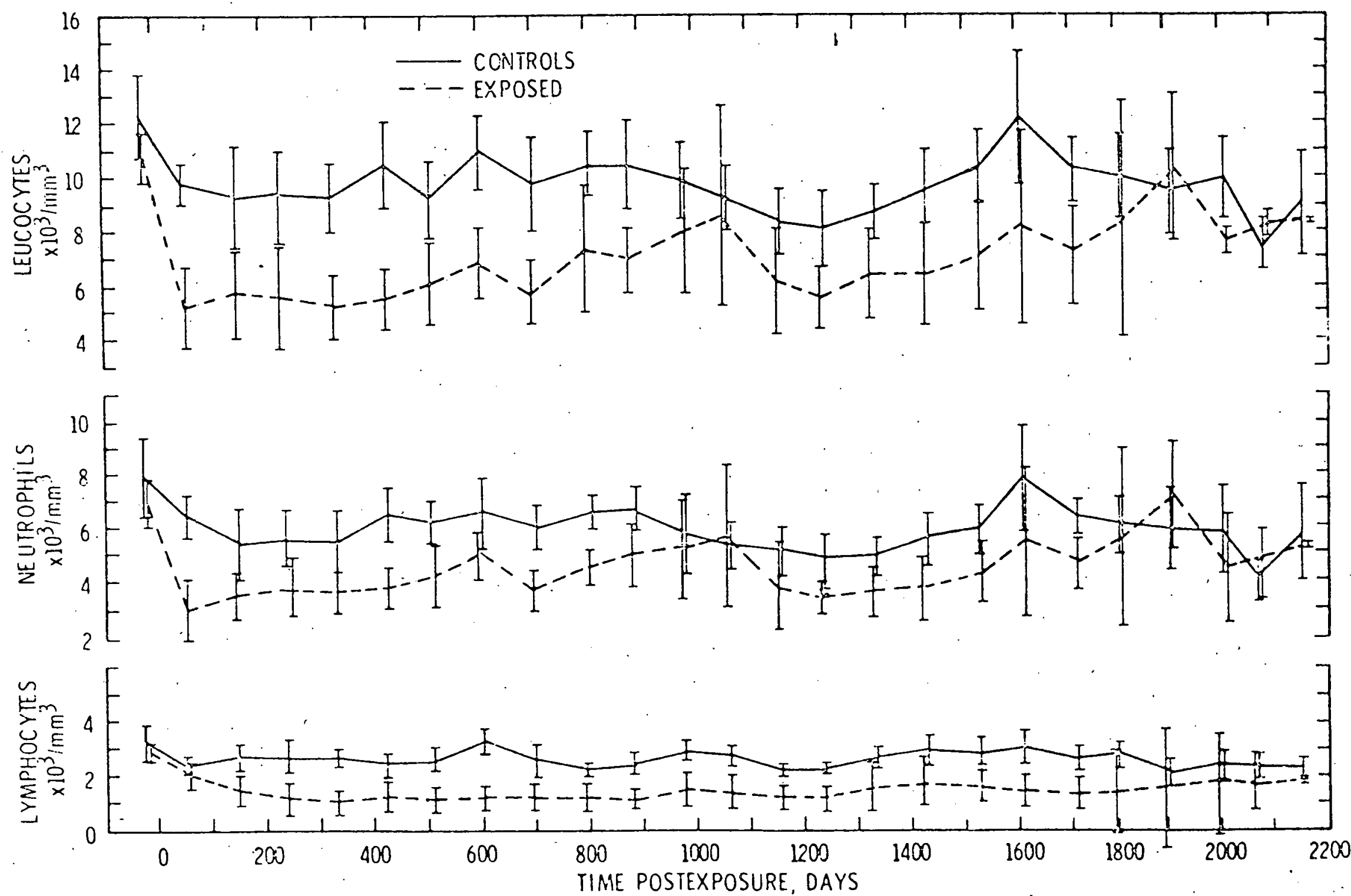


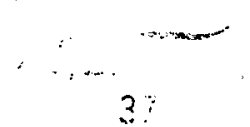

\section{FIGURE 6}

Leucocyte values of dogs after inhalation of ${ }^{238} \mathrm{PuO}_{2}$ crushed microspheres showing lymphopenia.

(lieàns $\pm 95 \%$ Cọnfidence Interval) 
LEUCOCYTE VÁLUES OF DOGS AFTER INHALATION OF ${ }^{238} \mathrm{PuO}_{2}$ CRUSHED MICROSPHERES (MEANS $\pm 95 \%$ CONFIDENCE INTERVAL)

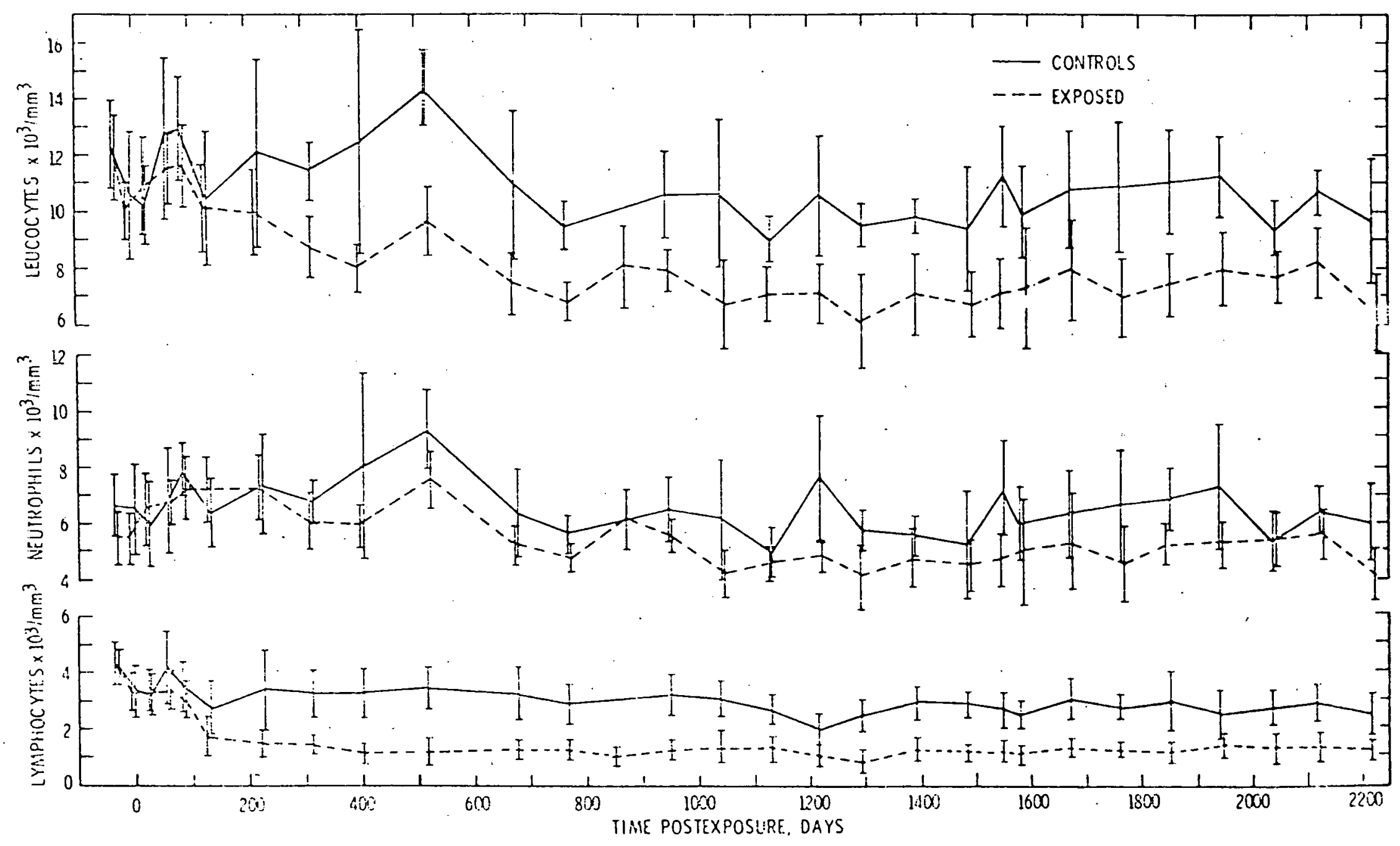




\section{FIGURE 7}

Leucocyte values of dogs after inhalation of $23 \mathrm{Pu}^{16} \mathrm{O}_{2}$ sho:4ing lymphopenia dose-response relationships.

(Means $\pm 95 \%$ Conficience Interval). 


\section{LEUCOCYTE VALUES OF DOGS AFTER INHALATION OF ${ }^{233} \mathrm{Pu}^{16} \mathrm{O}_{2}$ (MEANS $\pm 95 \%$ CONFIDENCE INTERVAL)}

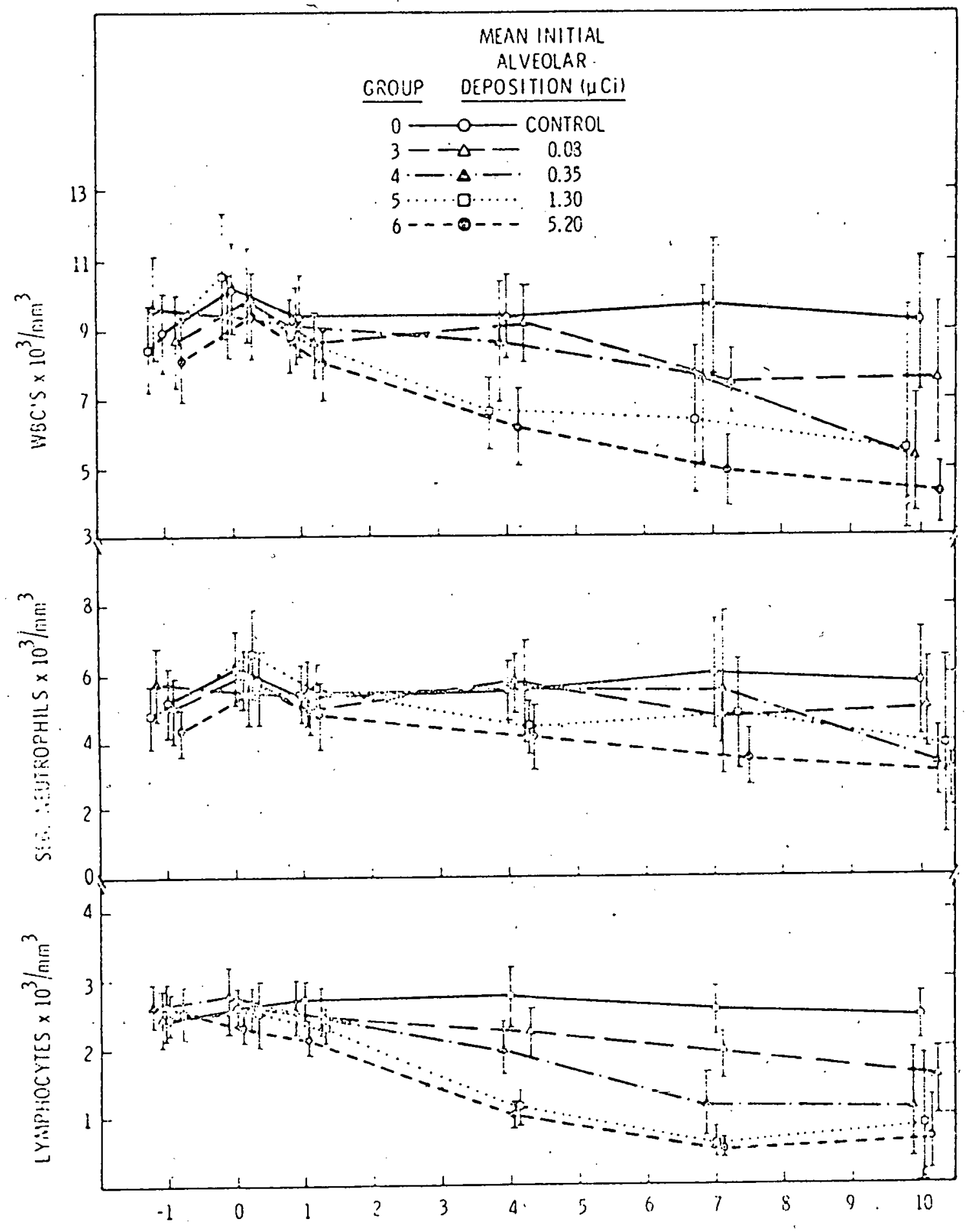

TIME POSE EXPOSURE WOONTHSI 